\title{
O KRIVOPUTSKOME GOVORU
}

\author{
Ankica ČILAŠ ŠIMPRAGA \\ Institut za hrvatski jezik i jezikoslovlje \\ Republike Austrije 16, 10000 ZAGREB
}

\section{DOSADAŠNJA ISTRAŽIVANJA KRIVOPUTSKOGA GOVORA}

\begin{abstract}
Codine 1911. objavio je Grga Tomljenović studiju Bunjevački dijalekt zaleda senjskog s osobitim obzirom
Ina naglas, a godinu dana kasnije bunjevačkim se govorom bavio Milan Japunčić te objavio rad u Nastavnom vjesniku br. XX pod naslovom “Osobine bunjevačkoga govora u Lici”. I dok je Japunčić sumarno donio najbitnija svojstva bunjevačkoga govora u Lici, Tomljenović je nastojao prikazati sve bitne fonološke i morfološke crte bunjevačkoga govora u senjskom zaleđu, a osobito je detaljno opisao naglasni sustav. $\mathrm{Na}$ to ga je potaknulo stajalište koje je prije stotinu godina bilo vrlo aktualno, a to je ono da su naglasci što su ih propisali Vuk i Daničić kanon novoštokavske standardne akcentuacije. Tomljenović kaže: Otkako je naime izišlo drugo izdanje Vukova rječnika (g. 1852), nije se više nitko usudio ni dirnuti u nepogrješivost Vukova akcenta. (Tomljenović 1983-1984:163) Tako je Tomljenović, upozoravajući na razlike između naglašavanja u zapadnom dijalektu, kojemu pripada i bunjevački govor, i Vukova naglašavanja, potaknuo mlađe akcentologe na daljnje proučavanje tih razlika i dokazivanje da zapadno novoštokavsko naglašavanje ima pravo biti temeljem hrvatske naglasne norme. ${ }^{1}$
\end{abstract}

\section{O METODOLOGIJI}

$\mathrm{K}$ rivoputski govor, o kojemu će biti riječi u ovom poglavlju, terenski je istraživan sredinom svibnja 2006. godine. (sl. 1) Građa je prikupljena intervjuiranjem lokalnoga stanovništva pomoću Upitnika za hrvatski jezični atlas, a velik dio podataka ekscerpirali smo s digitalnih snimaka spontana govora pouzdanih ispitanika. Riječ je o sljedećim ispitanicima: Milka Prpić Markina iz Veljuna, rođena Krmpotić, u Veljunu 1931. godine; Mara Tomljanović Isanova iz Krivoga Puta, rođena 1945. u Veljunu; Marko Pavelić Mijatin iz Podbila, rođen 1917.; Anka Šolić Tutanova iz Podbila, rođena Tomljanović, u Sibinju 1932; Ika Pavelić Tomina iz Mrzloga Dola, rođena 1925. i Milan Pavelić Vranićov iz Mrzlog Dola, rođen 1931. godine.

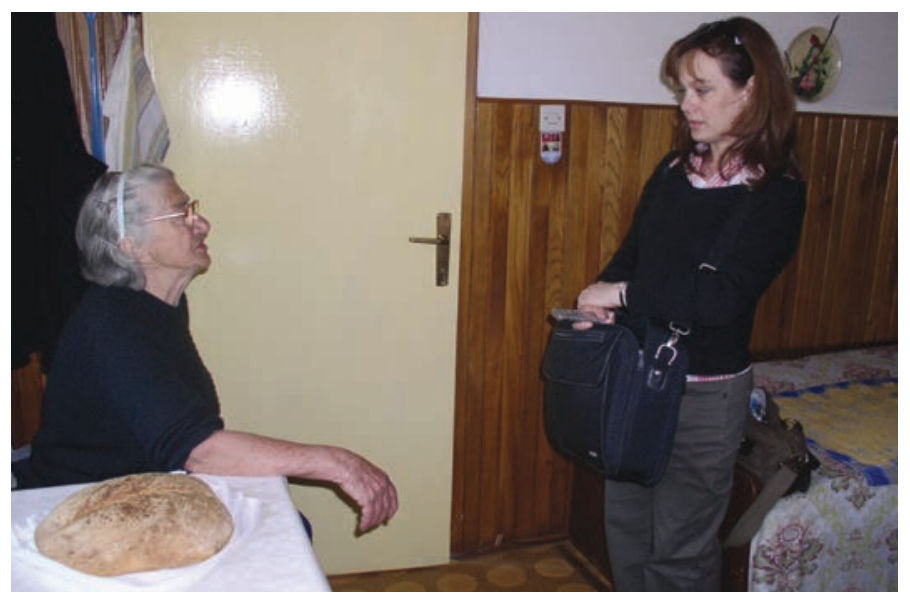

Slikea 1: Autorica u razgovoru s Ankom Šolić u Šolicima; snimila Marijeta Rajković, lipanj 2006. godine

\footnotetext{
V. Vukušić 1975. i 1985.
} 


\section{DIJALEKTNA PRIPADNOST KRIVOPUTSKOGA GOVORA}

$\mathrm{K}$ rivoputski govor pripada zapadnom dijalektu, koji se u dijalektološkoj literaturi naziva i zapadnim bosanskohercegovačkim dijalektom. Znači, riječ je o novoštokavskom ikavskom govoru.

Samo štokavsko narječje najveće je među trima hrvatskim narječjima. Ono se prostire velikim dijelom Hrvatske te mu pripada oko $50 \%$ govora.

Osnovne su značajke štokavskoga narječja postojanje zamjenice što, glas $u$ za $Q$ (muž od možb) i samoglasničko $l(v u k$ od $v l k b)$, promjena suglasničke skupine $\check{c} r>c r(c r n)$, promjena -lna kraju riječi ili sloga u $o$ ili u $a$, premetanje $v b s e \mathrm{u} s v e, u$ - od $v$-na početku riječi pred suglasnikom (unuk, udovac), nastavak -u u L jd. m. i sr. roda (u selu, u gradu), glas - $m$ ili $-n$ u I jd. ž. r. na -a (rukom, rukon), poseban oblik uz brojeve $2-4 \mathrm{u} \mathrm{m}$. i sr. rodu (dva, tri, četiri velika grada). Velika većina štokavskih govora umjesto poluglasa ima $a$, glas ćod jt (naći) i od tbj (braća), dod d'(meda), proširenje množine većine jednosložnih imenica m. r. umetkom -ov- (/-ev-), G mn. na -a, prenesen kratkosilazni naglasak "sa zadnjeg sloga, sačuvane nenaglašene dužine te jače ili slabije čuvanje aorista. Usto, u najvećem broju govora izgubljen je glas $x$, koji se čuva samo u dubrovačkom poddijalektu, dijelu Crne Gore i u bošnjačkim govorima (v. Brozović, 1965:269).

Uz te opće štokavske značajke, više od polovice govora zahvaćeno je tzv. novoštokavskim osobinama, a to su: nova akcentuacija i izjednačenje padežnih nastavaka u dativu, lokativu i instrumentalu množine.

\section{GRANICE ZAPADNOGA DIJALEKTA}

Z apadni se dijalekt prostire između istočne granice čakavskoga narječja, odnosno jadranske obale, na sjeveru do Save, odnosno do međe s kajkavskim narječjem u slijevu Kupe. Najveću ikavskoštokavsku cjelinu čine zapadna Hercegovina, dalmatinsko kopno te dijelovi zapadne i središnje Bosne. Usto ikavaca novoštokavaca ima u Bačkoj, oko Subotice, Sombora, oko Baje u Mađarskoj te u nekoliko naselja u Baranji. Tom dijalektu pripadaju i govori Maslinice na otoku Šolti, Račišća na Korčuli, Sumartina na Braču i Sućurja na Hvaru te tri hrvatska iseljenička govora u talijanskoj pokrajini Molise.

Današnje granice ovoga dijalekta uspostavljene su nakon 15. stoljeća, kad geografsku sliku dijalekata i narječja mijenjaju migracije stanovništva.

\section{BUNJEVAČKI I SENJSKI GOVOR}

$\mathrm{D}$ olaskom Bunjevaca u senjsko zaleđe u 16. stoljeću promijenila se jezična slika toga područja. U susjedstvo Senjana, čiji govor pripada srednjočakavskom dijalektu, doselili su se novoštokavci ikavci. Mnogi su se Bunjevci spuštali u Senj, no veći se broj počeo doseljavati tek nakon Prvoga svjetskog rata (Zečević 2000:179). Zbog tih je okolnosti jezično stanje u samom Senju vrlo kompleksno, tj. u odnos ulaze tri jezična sloja: senjska čakavština (supstrat), bunjevačka novoštokavska ikavica (superstrat) i standardni jezik (adstrat). Prema dijalektologinji Vesni Zečević u tome gradu mora se pratiti: a) senjski srednjočakavski dijalekt, b) bunjevački novoštokavski ikavski dijalekt, c) utjecaj senjskoga na bunjevački, d) utjecaj bunjevačkoga na senjski, e) utjecaj standardnoga jezika na senjski i f) utjecaj standardnoga jezika na bunjevački (Ibid.:178). V. Zečević uviđa također da "inovacijske pojave u senjskom govoru nemaju osobine dijalekatske obilježenosti bunjevačkoga govora" (Ibid.:181). Također, prateći govor Bunjevaca po naraštajima, konstatira slabljenje utjecaja senjske čakavštine u mlađih i jačanje utjecaja standardnoga jezika na njihov govor, koji je jezik prestiža i za Bunjevce i za Senjane. U čistim bunjevačkim brakovima u Senju uočava npr. nestajanje zatvorenosti dugih vokala $a$ i $o$, pokraćivanje zanaglasnih dužina te mijenjanje oblika pridjeva radnog. 


\section{1. Iz fonologije}

\section{1. 1. Vokalizam}

\section{1) Inventar samoglasničkog sustava}

U krivoputskome je samoglasničkom sustavu pet samoglasnika (a e i o u), koji dolaze u kratkim i dugim slogovima, a slogotvoran je i sonant $r$, koji također dolazi u kratkim i dugim slogovima (npr. p̈rst, č̀tvrtak). $\mathrm{Na}$ fonetskoj razini, tj. razini realizacije zamjetno je zatvaranje dugih samoglasnika $\bar{a}$ i $\bar{o}$ (npr. spâvậ 3. jd. prez., dộm). Samoglasnik se $o$, bio kratak ili dug, u govoru pripadnika treće dobi zatvara pred sonantima, npr. ọna, dọnosili, a potvrđene su zamjene $o>u$, npr. bumbóni, ûn, pùlìijia, ündā, ùna, únde. Zamjena $o>$ $u$, prema Dragičeviću, potvrđena je i u zavelebitskom području senjskoga zaleđa, gdje je npr. ùnāj, ündā.

Ta se zamjena gubi u govoru mlađih naraštaja.

\section{2) Vokalske zamjene}

Malo je vokalskih zamjena nenaglašenih samoglasnika, kakve su uobičajene u južnijim ikavskoštokavskim govorima, npr. poput onih u imotsko-bekijskim govorima u kojima je nòces 'noćas', pèčet 'pečat', livoda 'livada', vècara 'večera' itd. (Šimundić 1971:24-30). U Krivom su Putu potvrđene vokalske zamjene u imenicama pládeń 'tanjur' 'pladanj', bàdeń (uz bàdañ), taràpija 'terapija' te u drugim leksemima, uglavnom posuđenicama.

\section{3) Realizacija zanaglasnoga $i$}

Druga bitna značajka samoglasničkoga sustava na razini realizacije jest slabljenje zanaglasnoga samoglasnika $i$, tako se npr. pridj. rad. ž. jd. rádila može ostvariti kao [rádila], [rádila] ili kao [rádəla], dakle sa sačuvanom trosložnom strukturom. No moguće je i otpadanje zanaglasnoga $i$ : kòlko $(<$ koliko), tòlko (< toliko), kòprva.

\section{4) Ikavizam}

Bitno svojstvo krivoputskoga vokalizma jest ikavski refleks jata, npr.: dï 'gdje', döli 'dolje', göri, sîd, dìca, díte, mïsto, č̀vik, snîg, prïko, dìd, mlíko, vïdit, sìst inf., nèvista, závit, kòlino, glíto 'dlijeto', sìkira, klísta, vríme, dvî, svïtlo... No u tom se govoru javlja i određen broj stalnih ekavizama, npr. naprímer, dèlat inf., dèčko, pöslè, zënica, cèsta, starèsina, ónde, slèzēnka te jekavizama, npr. pjëšice (češće: nä noge), vjëžbat inf.

U razgovoru s došljacima, tj. govornicima drugih dijalekata Krivopućani se pokušavaju prilagoditi sugovorniku, bio on govornik standardnoga jezika ili senjske čakavštine. Stoga u razgovoru s govornikom standardnoga jezika s lakoćom jekaviziraju svoj govor, npr. mjësēe, nèvjesta, djëvêr, a razgovarajući sa Senjanima, nastoje poštovati pravila njihova ikavsko-ekavskoga govora te kažu: döle, göre, cêla, kòleno, svića itd.

\section{5) Samoglasnički skupovi}

Samoglasnički su skupovi potvrđeni, npr. àuto, no češće se gube ili stezanjem samoglasnika ili umetanjem suglasnika radi izbjegavanja zijeva.

a. Stezanje samoglasnika:

$a a>\bar{a}$ u pridj. rad. m. jd., npr. pìvā, glèd $\bar{a}$

ao $>\bar{a} z \hat{a} v a, \grave{o} r \bar{a}$

ae $>\bar{e}$ u brojevima $11-19$, npr. dvánēst, trínēst

$e a>\bar{e}$ u pridj. rad. m. jd., npr. pöčê, dòve (ali: ùzēja)

b. Umetanje suglasnika radi izbjegavanja zijeva:

- umetanje j: gríja G jd., pridj. rad. m. jd. vïdija, čüja. 


\section{6) Ostale značajke:}

a) U glagola tzv. II. vrste -nu- > -ni-: inf. sàgnit, mëtit 'metnuti', skïnit.

b) Kaže se gröb, gröble.

c) $\mathrm{Uz} u<v ə$, npr. ùnuk, udòvica, üvīk, rabi se i vremenski prilog vävīkl/vǟk, gdje je və > va. Tomljenović navodi vavik (v. str. 166.).

d) U imenici mäša 'služba Božja' prepoznajemo čakavski utjecaj, gdje je vokaliziran poluglas u slabom položaju, za razliku od leksema misa.

e) Stari prijedlog sə reflektirao se kao s, sa, so, npr. sàutīn, s nèdīlōn, $s^{2}$ ńîn; sa babètinan, sa gràvon, sò tīn.

f) Otpali su samoglasnici u početnom položaju:

$o->\emptyset \mathrm{u} v \grave{a} k \bar{o}$ 'ovako', vàk

a- >ø u Mèrika

g) Dodan je samoglasnik o pokaznoj zamjenici tî u početnom položaju: òt $\bar{l}$ (lúdi) analogijom prema pokaznoj zamjenici òvāj.

h) U doba Tomljenovićeva istraživanja krivoputskoga idioma govorilo se vrébac, nàrēst, no danas se češće govori ráste 3. jd. prez., vrábac, dakle sa sekvencom ra, umjesto starijeg re.

\section{1. 2. Konsonantizam}

\section{1) Afrikate}

U krivoputskome se govoru može čuti da isti informant kazuje [küća] i [küüa] te [čètri] i [četri]. Većina govornika "umekšano" izgovora bezvučnu afrikatu, dok je manje onih u kojih je taj glas vrlo "tvrd", tj. gdje je $[\check{c}]$ u $[k \ddot{u} \ddot{c} a]$ isti kao u riječi [ $[\check{e} t r i]$. Stoga se može zaključiti da je glavna značajka krivoputskoga

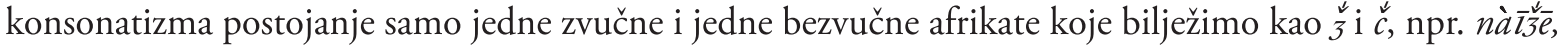
iž 3. jd. prez. 'ide', dovižéna te č̀vik, näčve. Slična je situacija i u zavelebitskom dijelu senjskoga zaleđa (Dragičević 1988:135). Prije gotovo stotinu godina Tomljenović je takvo stanje utvrdio samo u Alanu, dok je za ostala sela Krivoga Puta kazao da se u njihovu govoru dobro razlikuju $\check{c}$ i $c$, ali se slabije razlikuju $\breve{z}$ i 3́, za koje ponajviše dolazi 3 (Tomljenović 1984:170). Dakle, prije jednog stoljeća postojala je samo jedna zvučna afrikata, zbog čega je došlo do neravnoteže u sustavu afrikata $\dot{3}: \check{c}-\dot{c}$. Kako su bezvučne afrikate već tada pokazivale tendenciju ukidanja razlike $\check{c}-\dot{c}$, jasno je da je radi uravnoteženja u konsonatskome sustavu moralo doći do pojednostavnjenja, tj. smanjenja broja konsonanata.

\section{2) Štakavizam i šćakavizam}

Današnji krivoputski govor smatramo štakavskim jer nalazimo lekseme poput klísta, güstêr, štèta, ògńĭste, štâp, ülīste 'košnica'. Po tome se on sve više približava govoru zavelebitskoga zaleđa, s kojim ga u konsonatizmu povezuje i narušen standardni sustav afrikata te zamjena završnog - $m$ sa $-n^{3}$. No kako se, iako vrlo rijetko, u govoru starijih Krivopućana može čuti i ògńĭ̌̌cée, pretpostavljamo da je u prošlosti bilo više leksema sa šćakavskim refleksom, to jest da je govor Bunjevaca u senjskom zaleđu bio i štakavski i šćakavski. Tu pretpostavku potvrđuje i Tomljenović: Pored grupe šć (= stbj) govori se u nekim riječima $i$ št, ali rjecte, na pr.: kršćanin (i krštanin), namišćat (i namištat), oprašćat (i opraštat), raspušćat (i raspuštat) itd., a tako se govori i ognjišće (i ognjište - ognište), godišće (i godište) (Ibid.).

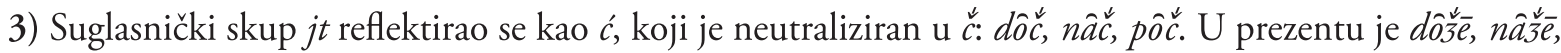
pồ̌é.

Prijedlog $\check{s}<s$ dolazi ispred palatala $\grave{n}$ zbog jednačenja po mjestu tvorbe.

3 Usp. Dragičević 1990:100. 


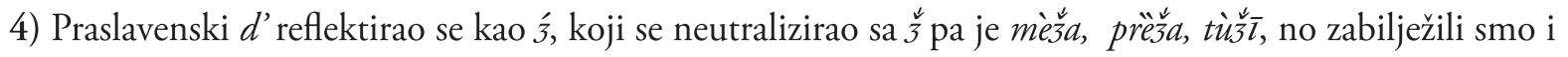
primjere sa j: göspoja, mèjās.

5) Kao i u mnogim govorima ikavskoštokavskoga dijalekta (od Bosne, cijeloga dalmatinskoga zaleđa između rijeke Krke i Neretve do ninskoga područja) i ovdje ima potvrda za nedosljedno novo jotovanje: rödijäk, nëtijäk 'sestrin sin'.

6) Fonemi $x$ i $f$ vraćaju se u krivoputski konsonantski sustav. Naime, za suglasnik je $x$ prije sto godina Tomljenović napisao: Glas h ne govori se nigda u $B^{4}$, ni u domaćijem ni u tudijem riječima. (Ibid.). O tadašnjem statusu suglasnika $f$ nije ništa rekao, no danas možemo konstatirati da oba ta suglasnika postoje u sustavu, ali je njihovo mjesto marginalno zato što često otpadaju ili su zamijenjeni drugim suglasnicima.

Primjeri:

a) Neki primjeri u kojima je fonem $x$ otpao: grâ, ödmā, òrā 'orao', sâmī G mn., špàret 'štednjak', vìr.

b) Neki leksemi u kojima je fonem $x$ zamijenjen fonemom $v$ (u intervokalnom položaju ili u finalnom položaju analogno prema kosim padežima): krüv, küvat, dùvān, gràva $\mathrm{G}$ jd., gràvon I jd., múve A mn., üvo, mávali pridj. rad. m. mn.

c) Neki primjeri u kojima je fonem $x$ zamijenjen fonemom $j$ : grijòta, gríja $\mathrm{G}$ jd.

d) Fonem $x$ zamijenjen je fonemom $k$ : siròmāk.

e) Neki leksemi u kojima je fonem $f$ zamijenjen fonemom $v$ : vört 'stalno', vàmīlija, vrâtar.

Fonemi $f$ i $x$, ponajviše pod utjecajem standardnoga jezika posredovanjem medija, a ne može se zanemariti ni utjecaj senjskoga govora u kojem ti fonemi postoje, pojavljuju se u govoru svih ispitanika, čak i najstarijih, u kojih smo našli i najviše potvrda za njihovo gubljenje. Tako isti govornik u razgovoru s ispitivačem kaže: špàrxet uz špàrket i špàret, krüv i krüx, grâ i gräx, küxat i küvat, vàmīlija i famīlijas. Potvrđeno je i: fála, fažōl, finno, fört, zatim xäla, Xèrcegovina, dìxān, xrána, küxińa, sùxa N neodr. ž. jd.

\section{7) Fonem - $l$ u završnom položaju}

a) U starijih govornika završno $-l>-e$ u pridj. rad. m. jd. glagola s osnovom na -i, npr. vòdije, vïdije, nòsije, pïje. No isti govornici govore i vòdija, vïdija, nòsija, pïja. Takva je dvojakost zabilježena i u zavelebitskom dijelu senjskoga zaleđa (Dragičević 1988:130). Zanimljivo je da je Tomljenović prije stotinu godina zabilježio samo -l >-all-ja (Tomljenović 1911-1912:169).

$\mathrm{U}$ ostalih glagolskih osnova $-l>-a$ ümrā, pïvā, rëk $\bar{a}$, čüja, dòve $(\bar{e}<e a)$, ìzēja.

b) U imenica je završno - lotpalo, npr. sô 'sol', vô 'vol', no zbog utjecaja ponajviše standardnoga jezika često se rabe i leksemi s restituiranim završnim -l, npr. stôl.

c) U jednosložnim i dvosložnim pridjevima muškog roda u nominativu jednine - $l$ je također restituiran, npr. bîl, cîl, vësel, dèbel.

\section{8) Fonem - $m$ u završnom položaju}

Fonem je - $m$ na kraju nastavačnih morfema prešao u -n: èsan 'jesam', ïmān, u svàkōn $\mathrm{L}$ jd. sr., sàutīn, kàmēnon I jd., gödinan I mn. itd.

9) U nesvršenom prezentu glagola bït inicijalno je-dalo je e-: èsan, èsi, èst, èsmo, èste, èsu.

10) Prejotacija nije česta: jápno $\sigma^{6}, j o ̈ p \bar{e} t$, ali i öpèt.

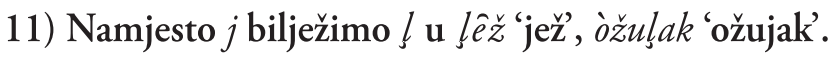

Simbol "B" odnosi se na "bunjevački dijalekt".

"Vàmīlija, fâmīlija, kàko göd", rekao nam je 89-godišnji kazivač Marko Pavelić Mijatin.

Imenica vapno potječe od baltoslavenske riječi vap̧ 'boja'. Fonem $v$ pripada osnovi, no u hrvatskome je bio shvaćen kao proteza, koja je zamijenjena protezom $j$-. (v. Skok, III, 565) 
12) Rotacizam, tj. prijelaz $\check{z}>r$ zabilježili smo u prezentu glagola möc: mören, nè meren, möreš, möre. No javljaju se i dubletni oblici möžeš, möže.

13) Navezak -n dolazi u prilozima i zamjenicama: ôvlēn 'odavde', ödlēn, ödotèn, ödmān 'odmah', ündān, š níman I zamjenice 'oni'.

\section{4) Suglasnički skupovi}

Suglasnički se skupovi pojednostavljuju zamjenama suglasnika unutar njih ili ispadanjem jednog od suglasnika.

a) Primjeri zamjene unutar suglasničkih skupina:

\begin{tabular}{|c|c|}
\hline 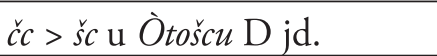 & $d l>g l \mathrm{u}$ glíto \\
\hline$g n>g n ́ \mathrm{u}$ gńízdo & $m n ́>m_{\mathrm{s}} l \mathrm{u}$ súmlati \\
\hline$m n>m l \mathrm{u}$ osàmlèst & $m n>v n$ u gúvno \\
\hline$m t>n t \mathrm{u}$ pântīn 1. jd. prez. & $s f>s v$ u $\grave{a} s v \bar{a} l t$ \\
\hline svr > švr u švräka & \\
\hline
\end{tabular}

b) Primjeri ispadanja fonema iz suglasničkih skupova:

\begin{tabular}{|c|c|}
\hline$d n>n$ u pänē 3. jd. prez. 'padne' & $d s>s$ u osič̀ena pridj. trp. ž. jd. \\
\hline$g l>g$ u gísta 'glista' & $g d>d \mathrm{u} d \ddot{l}$ 'gdje' \\
\hline$x v>v$ u ùvati, vätāj 2 . jd. imper. & $k v>k \mathrm{u} t \grave{a} k \bar{l}$ \\
\hline$r n>r$ u sïgūro 'sigurno' & $p \check{c}>\check{c} \mathrm{u} \check{c} \ddot{l} l e$ \\
\hline$p \check{s}>\check{s} \mathrm{u}$ šenica & $p t>t \mathrm{u}$ tïce \\
\hline$s l>s$ u blägosov & svr $>$ sr u sirbit inf. \\
\hline$t k>k \mathrm{u} k \ddot{o}, n i ̈ k o$, sväko & tstv > stv u bògastvo \\
\hline$v d>d \mathrm{u}$ óde & $z g l>z l \mathrm{u} z l o ̄ b$ 'zglob' \\
\hline
\end{tabular}

c) Treća je promjena unutar suglasničkih skupova umetanje suglasnika $d$ u skup $z r: z d r a ̂ k$. Ta se promjena čuva samo u najstarijih govornika.

\section{5) Otpadanje i dodavanje slogova}

a) U ulozi navezaka dolazi slog -ka, koji se ponajprije veže uz priloge, npr. jes̀enaska, dolíka, i slog -zi, koji se veže uz zamjenice, npr. tïzi G zamjenice 'ti', ńôjzi D zamjenice 'ona'.

b) Središnji slog otpada u često rabljenom 2. licu množine imperativa sljedećih glagola: öte 'odite', vïte 'vidite', àjte 'hajdete'.

\section{1. 3. Naglasci}

Krivoputsku novoštokavsku akcentuacija kakva je bila prije stotinu godina sustavno je opisao Grga Tomljenović u navedenom radu. Riječ je o četveronaglasnom sustavu (" - " ) sa zanaglasnom dužinom is novoštokavskim distribucijskim pravilima. Premda naše istraživanje nije obuhvatilo tako opsežnu naglasnu problematiku kao Tomljenovićevo, utvrdili smo da se taj naglasni sustav dobro čuva. Stoga navodimo samo neke njegove značajke:

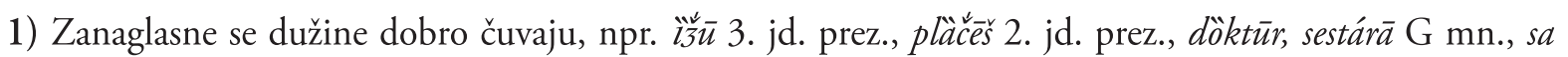
žènōn, pïvāj 2. jd. imp., dōbrōj D jd., krä̀̆

\section{2) Pomicanje naglaska na proklitiku.}

a) Naglasak se pomiče na proklitiku kad se ona nađe ispred riječi naglašene silaznim naglaskom, npr. isprìt

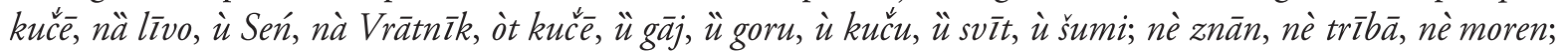

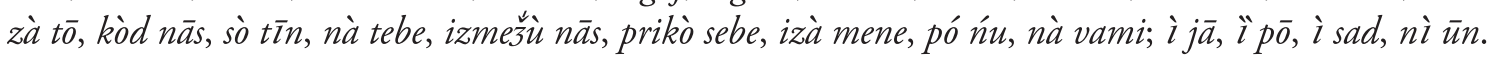


b) Kad je imenica u množini, naglasak se ne pomiče na proklitiku, npr. na kölīn, u lökvan, na gäăan, po nívan.

c) Ima potvrda za nepomicanje naglaska na proklitiku i kad je imenica u jednini, npr. u drägu, u Krîvoñ Pútu, u šümu, na dësno, na cèsti, po slïki, na zëmlu, na rad, na zîmu, na snîg.

d) Nepomicanje i pomicanje naglaska na proklitiku pojavljuje se u govoru iste osobe, npr. nà Velūnu // na Vềūnu, nà pă̌u // na pä̌su.

3) U trosložnih glagolskih pridjeva radnih ženskog roda dugouzlazno je naglašen drugi slog, npr. udála, pozvála, prolíla, umŕla, odníla, uzéla. Taj naglasak zadržavaju i njihove izvedenice, npr. preuzéla. No moguć je i preneseni kratkosilazni naglasak na prvom slogu, npr. ödnīla.

4) Glagoli poput bït, pït itd. imaju u glagolskom pridjevu radnom sljedeći naglasni odnos: bijjel/bïja bíla - bîlo - bîle - bîli - bîla.

5) Glagoli poput rëc, lëc, pë̌́c itd. imaju u glagolskom pridjevu radnom u sva tri roda kratkosilazni naglasak: rëkā - rëkla - rëklo.

6) Naglasni tip neodređenog vida pridjeva bôs - bòsa - böso - bösi - böse - bösa razlikuje se od standardnoga jezika u kojem su prema Hrvatskoj gramatici (Barić 1997:187) moguće naglasne dublete bösalbòsa - bösol bòso - bösilbòsi - böselbòse - bösalbòsa.

7) Naglasni tip neodređnog vida pridjeva čìst - čcista - čcisto također se razlikuje od standardnoga jezika u kojem su dopuštene naglasne dublete u ženskom i srednjem rodu. Tom tipu pripadaju i pridjevi $z d r a ̀ v-$ $z$ dràva - zdrävo, növ - nòva - növo, spör - spòra - spöro itd.

8) U genitivu množine muškog roda naglasak je na korijenskom morfemu, npr. gölūbovā, vrägōvā, a ne golubóvā, vragóvā.

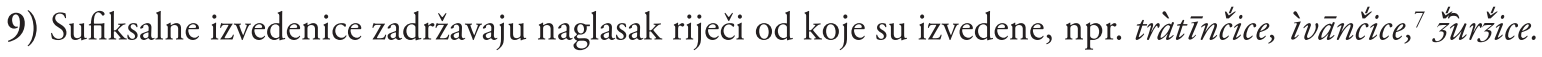

10) Neki se leksemi naglasno razlikuju od standarda, npr. májka, ôsa, spûžvica, želúdac, Spásitel, süza, rïbat 'čistiti, prati trljajući četkom’.

\section{2. Iz morfologije}

\section{Glagolski oblici}

1) Infinitiv je bez $i$, npr. dồ, dèlat, mòlit.

2) Imperfekt je nestao iz sustava glagolskih oblika.

3) Aorist se dobro čuva, npr.: Zäkle se da je ìstina; Svëkrva mi rë̌́e da če dồc.

4) O pridjevu radnom muškog roda jednine v. poglavlje 'Iz fonologije - Konsonantizam' t. 7) a).

5) U infinitivu se rabi glagol živit, no u prezentu se češće upotrebljavaju oblici glagola žìvsti - žíven, žíveš,

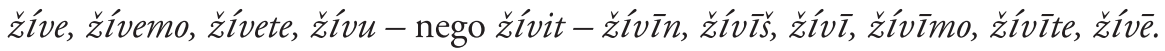

6) Glagoli prve vrste poput pït i lït u 2. jd. imperativa nemaju $-j$ : $p \hat{\imath}, l \hat{l}$, pòp $\bar{\imath}$, nàlī.

I m e n ice

1) Sklonidba imenica pretežno je novoštokavska, što znači da ima i arhaičnijih deklinacijskih oblika.

2) U dativu i lokativu imenica koje se sklanjaju po e-sklonidbi osnova je desibilarizirana, npr. L jd. po nògi, u Rijéki, májki.

\footnotetext{
U primjerima tràtīnčice, ìvānčice došlo je do duljenja zadnjeg sloga osnove pred sonantom.
} 
3) Imenice i-sklonidbe u instrumentalu jednine imaju nastavak -i, npr. sa söli, s kösti.

4) Česta je tzv. kratka množina, npr. $\mathrm{N}$ mn. mǐsi, vòli, púti, međutim i najstariji govornici rabe i tzv. dugu množinu s interfiksom -ov-, npr. zëcovi, vükovi, špágovi, no i s-ev-, npr. pútevi, púževi. Češća uporaba neproširenih množinskih forma te uporaba duge množine $s$-ov-a ne $s$-ev-karakteristika je bunjevačkoga govora širega područja, a ne samo senjskoga zaleđa.

5) U genitivu množine dolazi nastavak $-\bar{a}$ za imenice a- i e-deklinacije te $-\bar{l} /-i$ za imenice i-deklinacije. Po posljednjoj paradigmi sklanja se i imenica mëter 'metar', npr. pêt mëteri. Stari nastavak -ø u genitivu množine zadržavaju imenice gödina i stötina kad uz njih dolaze brojevi veći od četiri, npr. pê gödīn, ösan stötīn.

6) Množinski su padežni nastavci ujednačeni u dativu, lokativu i instrumentalu - za muški i srednji rod -īn (D L I lúdīn, kölīn), a za imenice ženskoga roda e-deklinacije -an (D žènan, L u kǚ̆an, I s bäban). Oblike na -mi (rukami, ženami), za koje je Tomljenović prije stotinu godina rekao da su rijetki, danas više ne nalazimo u krivoputskome govoru. Također, u mlađih se govornika, pod utjecajem medija i obrazovnog sustava, u D L I množine javljaju nastavci -ima u imenica muškog i srednjeg roda te ženskog roda na suglasnik, a nastavak -ama $\mathrm{u}$ imenica ženskog roda.

7) Imenice i-deklinacije imaju u D L I nastavak -in, kao i imenica čêr. Imenica mater sklanja se kao imenice e-deklinacije. Slična su ujednačenja provedena i u bunjevačkom govoru zavelebitskoga područja te sjevernovelebitskoga gorja (primjer govora Krasnoga Polja). ${ }^{8}$

8) Genitiv imenice päs jest $p s \ddot{a}$.

Pridjevi

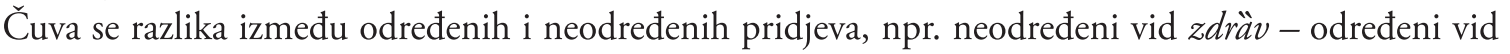
$z$ drävī.

B rojevi

1) Zbirni se brojevi od glavnih brojeva većih od tri tvore pomoću nastavka -ero: sëdmero, ösmero.

2) U doba Tomljenovićeva istraživanja krivoputskoga govora brojne su imenice ispred nastavka -ica čuvale formant -ero-pa je bilo peterica, šesterica (Tomljenović 1911-1912:208). Danas se uz te oblike upotrebljavaju i oni s formantom -oro-, tj. petòrica, šestòrica.

Z a m je n ice

1) Lične su zamjenice $j \hat{a}, t \hat{\imath}, \hat{o} n$, òna, òno, $m \hat{\imath}, v \hat{\imath}$, òni, òne, òna. U najstarijih govornika došlo je do $o>u$

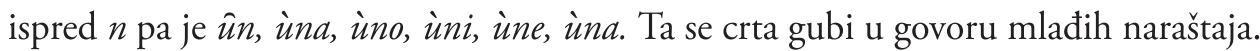

Primjeri sklonidbe:

a) Sklonidba zamjenice $t \hat{\imath}$ : N tî, G tëbe, D tëbi, A tëbe, L tëbi, I töbōn.

b) Sklonidba zamjenice vî: $\mathrm{N} v \hat{\imath}, \mathrm{G}=\mathrm{A}$ vas/vas, $\mathrm{D} \mathrm{L}$ I van/vämi/väma.

2) Upitna zamjenice za neživo jest šttô, a njezin je genitiv čèga. Nije potvrđen oblik čêsa, koji Tomljenović navodi kao jedini u upotrebi prije stotinu godina (Tomljenović 1911-1912:207).

3) Neodređenim zamjenicama 'nišsta' i 'išta' otpao je završni slog -ta pa one glase nǐš i ǐs.

4) Pokazna zamjenica za muški rod jest tâj, a nije potvrđen oblik tâ, koji je Tomljenović istaknuo kao vrlo čest početkom 20. stoljeća (Ibid. 206).

8 V. Dragičević 1989 i 1990. 


\section{3. Iz sintakse}

Od sinatktičkih crta izdvajamo uporabu:

1) krnjeg perfekta: Dëve gödīn lèžala u krèvetu; E, tô mëni svëkrva kaživala; Čúvali lìvade da ne bi blâgo tù̌̆ päslo.

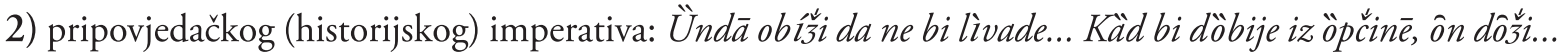
Po trî-čètri sâta mî büdi u dnêvnōn. (dnêvnōn < dnêvnōn bòrāvku); Stô kr̂pā büdi na gäčan.

3) drugog lica jednine glagola u prepričavanju prošlih radnji/događaja: İmā je dvî ònē prêgredice pa si jèdnu däsku mëtnija tàkō ïpāk da pëpel...

4) obezličenoga historijskog imperativa: Lïti se kúpi mêsa... Za màrēndu se spèci mêsa.

5) bezličnih rečenica: Obòlalo i štö möžemo; Tû se vätra ložila i küvalo se sa stráne.

6) neokrnjenog infinitiva na kraju rečenice za isticanje glagolske radnje: Nè mogū stâri lâudi vǐše ráditi; E, níje ündā óde dòbro bïti. - No moguća je uporaba i krnjega infinitiva u takvoj situaciji: Kòd ńn si mórā bït.

7) konstrukcije "glagol znati + infinitiv" za uobičajenu radnju koja se u prošlosti ponavljala: Znäle su òne, Cìgānke, pròsit... Žèlezo su znäli brät dì bi lûdi bácili.

8) osobne zamjenice radi postizanja napetosti: ... ǐ̌̌emo mî u drägu, käd tämo... (Riječ je o prepričavanju susreta s medvjedom.)

9) također ističemo da neki glagoli nisu povratni, npr. šétat, odsèlit, nàviknut: Onàkō šéci pa vïdi; To su Jûdi odsèli li; Mî smo tû nàvikli na zîmu i na snîg.

Iz sintakse padeža izdvajamo:

1) Uporaba vremenskoga genitiva: Jesèni su se kläle svîne.

2) Instrumental društva dolazi s prijedlogom $s$, no i instrumental sredstva najčešće ima taj prijedlog, npr.: $S$

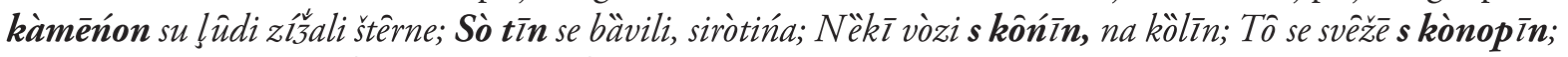
Säd se vözī s àuton; Pề̃ se lòžla s dùgāčkin dìvīn.

No instrumental sredstva dolazi i bez s: Sîn se bävī òbrton; mávali nògōn. Teško je utvrditi pravilo kad uz instrumental sredstva dolazi prijedlog $s$, a kad ne dolazi. $S$ druge strane, ima situacija kad se instrumental društva rabi bez s, npr.: Sâm söbōn se mòraš i nasmìjat.

3) Instrumental s vremenskim značenjem: prijedlog $s+$ dan u tjednu za radnje koje su se običavale događati

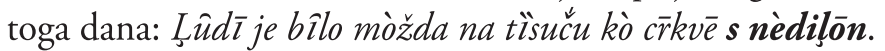

\section{O LEKSIKU}

U leksiku je manje turcizama nego u južnijim i istočnijim govorima zapadnoga dijalekta. Tako ne nalazimo lekseme poput avlija i pendžer, nego dvòrišste i prózor. Od raširenih naziva predmeta turskoga podrijetla i ovdje se rabi jàstuk.

Među leksemima tipičnima za senjsko zaleđe jesu stara posuđenica iz furlanskoga pládeń 'tanjur', venecijanizam pàdela 'zdjela', ekavizam dèlat 'djelati, činiti, raditi', romanizam bêrma 'krizma', germanizmi špàret 'peć', kïkla 'suknja' i mêrlin 'mrkva', regionalizam škûla 'rupa' te stara slavenska riječ däžd 'kiša'. Grecizam 'metar' u krivoputskom je govoru mëter.

Za neke odjevne i predmete za svakodnevnu uporabu ne rabe se posuđenice nego domaće riječi, npr. záslon 'pregača', rúbac, rǚ̌nīk. Glagol brät sačuvao je značenje 'skupljati' u sintagmi brät žèlezo.

Neki prilozi drukčije zvuče nego u standardnom jeziku ili pak imaju drukčije značenje, npr. nëkadēe 'katkad', òzdā 'odozada', òzgār 'odozgo', ìzmed 'između' (tako je i u Senju). Česte su kontrakcije složenih veznika ili veznika i priloga, npr. kända 'kao da' (Kända jâ znân) i pändā 'pa onda'. Prijedlog pr̈vo znači 'prije', npr. pirvo räta. Prijedlog rädi uz značenje namjere dolazi i u uzročnom značenju: Tô je tòlkō plîs,

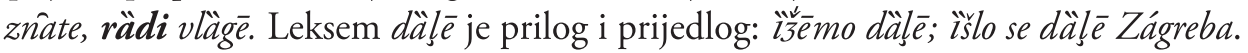




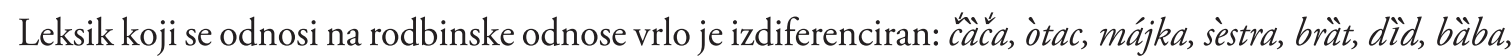
üjac, ûjna, tétak, tëtka, strîc, strîna, nëtijäk, sinóvac, dïvèr, jêtrva, zâva, pầs, svëkar, svëkrva, tâst, pünica.

Uzrečica vrâga služi za iskazivanje neslaganja, npr. A vrâga je òna znäla.

Ojkonim Brinje u krivoputskome je govoru prešao u muški rod te glasi Brïń. Antroponim Títo sklanja se po e-paradigmi: N Títo - G Títe.

\section{ZAKLJUČAK}

$\mathrm{U}$ vokalizmu novoštokavskoga govora Krivoga Puta najvǎnija je značajka ikavski refleks jata (dìca, díte, dìd, mlíko, vïdit) uz određeni broj stalnih ekavizama i jekavizama. Na fonetskoj razini zamjetno je zatvaranje dugih samoglasnika $\bar{a}$ i $\bar{o}$ (npr. spậvă 3. jd. prez., dộm) te kratkoga i dugoga $o$ ispred sonanta u

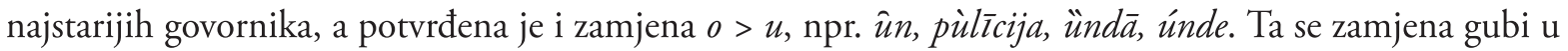
govoru mlađih naraštaja.

Glavne su značajke krivoputskoga konsonatizma postojanje samo jedne zvučne i jedne bezvučne afrikate

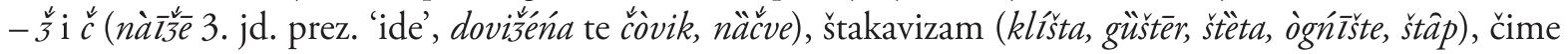
se ovaj govor sve više približava govoru zavelebitskoga zaleđa, te prelazak - $m$ u $-n$ na kraju nastavačnih morfema (èsan 'jesam', u svàkōn L jd. sr., sàutīn I jd., gödinan I mn. itd.).

Kao inovacija u konsonatskom sustavu uočeno je vraćanje fonema $x$ i $f$ u krivoputski konsonantski sustav. Što se tiče završnoga -l, u imenica je taj glas otpao, npr. sô 'sol', vô 'vol', no rabe se i imenice te pridjevi s restituiranim završnim -l, npr. stôl, bîl, cîl, vësel, dèbel. U glagolskom pridjevu radnom muškoga roda glagola s osnovom na -i u starijih govornika, kao i u zavelebitskom zaleđu, $-l$ je prešlo u -e npr. vïdije, nòsije, pïje. No isti govornici govore i vòdija, vïdija, nòsija, pïja. Takva je dvojakost zabilježena i u zavelebitskom dijelu senjskog zaleđa. U ostalih glagolskih osnova $-l>-a$ ümrāa, pìvā, rëkā, čüja, dòve $(\bar{e}<e a)$, ùzéja.

Od morfoloških značajki uočene su inovacije u množinskim padežnim nastavcima. Naime, uz ujednačene nastavke u dativu, lokativu i instrumentalu - za muški i srednji rod -īn (D L I lúdīn, kölīn), a za imenice ženskoga roda e-deklinacije -an (D žènan, L u kǚ̆an, I s bäban), u mlađih se govornika, pod utjecajem medija i obrazovnog sustava, u D L I množine javljaju nastavci -ima u imenica muškog i srednjeg roda te ženskog roda na suglasnik, a nastavak -ama u imenica ženskoga roda.

\section{OGLEDI GOVORA}

Koza

Kòza se tâj špà̀ret zvâ. I níje döli nǐsta ìmā, nïti kùtijê, nïs, nëgo si mögāa mëtit. İmā je dvî ònē pregredice pa si jednu däsku mëtnija tàkō ïpāk da pëpel... Ôn je pädā, imāa je kùtiju, àli ïpāk bi pädā. I mälo dŕvā slòzi. I tàkō tâ kòza. To je imala säd jöš nëdāvno mòja ûjna, äl tô je sämo mögla kúpit göri nëgdi u Òtošcu.

(Anka Šolić Tutanova, r. 1932. u Sibinju, živi u Krivome Putu)

\section{Pranje rublja}

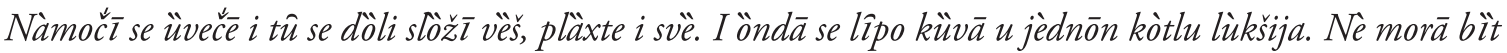

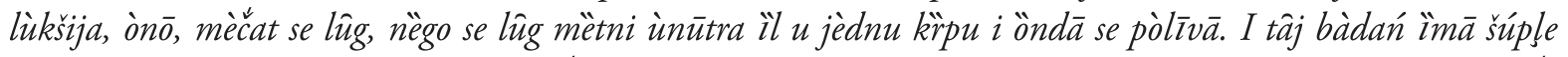

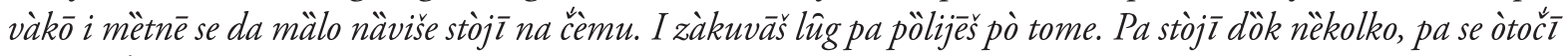

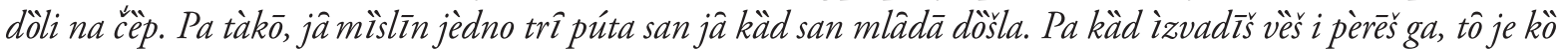
sûnce bijélo i čìsto. Níje nïkakvā práška bîlo ù ńemu nï̀ti nïčega. Níje se ni ìspirā kòlko se òvāj ìspirēe. Níje ni vòdē bîlo tàkō.

(Anka Šolić Tutanova, r. 1932. u Sibinju, živi u Krivom Putu) 


\section{Gradnja baraka}

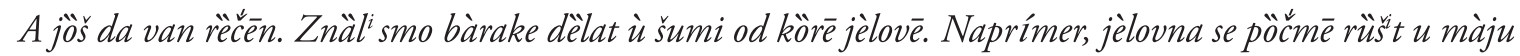
ïl säd se rǚš̄ i ündā se síce na mèter i vùdā se rasíce... I öndā se sò tīn bàraka dëlala, krïla... E, da je tô bîlo vïdit, da je vämi ündā bîlo.

(Milan Pavelić Vranićov // Joletin, r. 1931. u Mrzlom Dolu)

\section{Cigani}

(Jesu li dolazili prije Cigani?)

O, Cïgani su tùdā pròlazili. Pr̈vo bîlo Cïgānā, mëni je svëkrva kaživala. Öndā se, vèlī, pâr miséci smjèsti, nïgdi sätore razgŕni. Sàda nêmā. Säd òvī kòjī röbu vözēe, znáte, ńî zòvemo da su Cïgani, Makedónci.

(Što vam je svekrva pričala, oni su znali tu biti?)

Dä, lógorovati, büdi po pâr miséci... Nísu òni nïkome prävili na zèmli smétńu. Nëgdi kräju. I öndā po

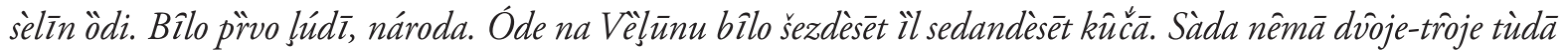
nâs pâr stârī vrägōvā.

(Milka Prpić Markina, r. 1931. na Veljunu)

\section{LITERATURA}

BARIĆ, Eugenija i dr. (1997²): Hrvatska gramatika. Školska knjiga, Zagreb.

BROZOVIĆ, Dalibor (1965): Štokavsko narječje. Školski leksikon, Jezik, Panorama, 265-273, Zagreb.

BROZOVIĆ, Dalibor (1970): Dijalekatska slika hrvatskosrpskoga jezičnoga prostora. Radovi Filozofskog fakulteta u Zadru, 8: 5-30 + karte, Zadar.

BROZOVIĆ, Dalibor (1985): Suvremeno štokavsko narječje kao plod konvergentnoga jezičnoga razvoja. Hrvatski dijalektološki zbornik, 7, sv. 1:59-71, Zagreb.

ČILAŠ ŠIMPRAGA, Ankica (2002): Fonologija ikavskih štokavskih govora između rijeke Krke i Neretve, Zagreb (magistarski rad u rukopisu)

DRAGIČEVIĆ, Milan (1988): Važnije osobine glasovnog sustava govora sela Vratnik iz zavelebitskog dijela senjskog zaleđa. Zbornik Pedagoškog fakulteta u Rijeci. 9-10:129-143. Zagreb.

DRAGIČEVIĆ, Milan (1989): Morfološke osobine imeničkih riječi u govoru Bunjevaca iz zavelibetskog dijela senjskog zaleđa. Fluminensia, I, 1:112-121. Rijeka.

DRAGIČEVIĆ, Milan (1990): O današnjem ikavskom govoru u Krasnom Polju. Fluminensia, II, 1-2: 96-102. Rijeka.

JAPUNČIĆ, Milan (1911-1912): Osobine bunjevačkog govora u Lici. Nastavni vjesnik, XX, 266-273.

LISAC, Josip (2003): Hrvatska dijalektologija 1. - Hrvatski dijalekti i govori štokavskog narječja i hrvatski govori torlačkog narječja, Zagreb.

LISAC, Josip (2003): Fonologija novoštokavskoga ikavskog dijalekta. Rasprave Instituta za hrvatski jezik $i$ jezikoslovlje, 29:173-180, Zagreb.

LUKEŽIĆ, Iva (1998): Štokavsko narječje, Radovi Zavoda za slavensku filologiju, 32:117-135. Zagreb.

MOGUŠ, Milan (1954): Izvještaj o istraživanju narodnih pomorskih naziva u Podgorju u god. 1952., Ljetopis, 59:193-196. 
MOGUŠ, Milan (2002): Senjski rječnik. Hrvatska akademija znanosti i umjetnosti - Matica hrvatska Senj. Zagreb-Senj.

PECO, Asim (1986): Ikavskoštakavski govori zapadne Hercegovine. Djela ANUBiH, LXI, Odjeljenje društvenih nauka, knj. 35, Sarajevo.

SKOK, Petar (1971-1974), Etimologijski rječnik hrvatskoga ili srpskoga jezika. Knj. I-IV, JAZU, Zagreb.

ŠIMUNDIĆ, Mate (1971): Govor Imotske krajine i Bekije. Djela ANUBiH, 41, Odjeljenje društvenih nauka 26, Sarajevo.

TOMLJENOVIĆ, Grga (1983-1984): Bunjevački dijalekt zaleda senjskog s osobitim obzirom na naglas, Gradski muzej Senj, Senj.

VUKUŠIĆ, Stjepan (1975): Naglasci imenica muškog roda u sjevernopodgorskom govoru. Senjski zbornik, 6:495-514, Senj.

VUKUŠIĆ, Stjepan (1985): Hrvatska naglasna norma na osnovi zapadnog dijalekta (ikavaca). Hrvatski dijalektološki zbornik, 7, sv. 1:275-290, Zagreb.

ZEČEVIĆ, Vesna (2000): Hrvatski dijalekti u kontaktu, Institut za hrvatski jezik i jezikoslovlje, Zagreb. 